\title{
STRENGTH CHARACTERISTICS OF ALCCOFINE BASED LIGHT WEIGHT CONCRETE
}

\author{
L J Sanjeev Kumar \\ Graduate student, School of Civil Engineering, SASTRA Deemed to be University, \\ Tamilnadu, India \\ P Bhuvaneshwari \\ Assistant Professor, School of Civil Engineering, SASTRA Deemed to be University, \\ Tamilnadu,India

\section{Moka Eswar} \\ Graduate student, School of Civil Engineering, SASTRA Deemed to be University, \\ Tamilnadu, India

\section{K Aditya Subramanian} \\ Graduate student, School of Civil Engineering, SASTRA Deemed to be University, \\ Tamilnadu, India
}

\begin{abstract}
Concrete being an important material for construction of various structures has severe demand in the present trend of construction industry. Aggregate occupies the major quantity (70\% approx.) of concrete based on which characteristics like compressive strength and porosity are controlled. The present usage of aggregate for construction is resulting in the depletion of the natural resources as well as it is showing a great impact on the environment. The work is to focus on the strength characteristics of concrete using coconut shell as an alternative material obtained from coconut processing units. Based on earlier studies a nominal amount of $30 \%$ replacement of natural coarse aggregate with coconut shell has been fixed. 'Alccofine' is used as a mineral admixture by replacing cement at various proportions in order to supplement the loss of strength. Tests have been carried out to find out the dry density, wet density and compressive strength. Comparison of the results show that the 30CS A8 (M4) achieving less density without compromising the strength.
\end{abstract}

KEY WORDS: Light weight concrete; Coconut shells; Alccofine; Density; Compressive strength; 
Cite this Article: L J Sanjeev Kumar, P Bhuvaneshwari, Moka Eswar and K Aditya Subramanian, Strength Characteristics of Alccofine Based Light Weight Concrete, International Journal of Advanced Research in Engineering and Technology, 10(1), 2019, pp 268-275..

http://iaeme.com/Home/issue/IJARET?Volume $=10 \&$ Issue $=1$

\section{INTRODUCTION}

\subsection{General}

Concrete has been widely used in the construction industry. It composes of fine aggregate and coarse aggregate along with fluid cementitious composite providing good bond. Lightweight concrete gaining high demand in today's world is all because of its improved thermal properties, reduced self-weight of structural members and its mobility.

Due to the rapid development in the construction sector, the usage of natural sources as aggregates are depleting leading to scarcity. In order to balance the effect, alternative materials need to be found as a replacement of aggregate without any loss in their properties. Experimental investigation was performed to analyze the effects of replacing the conventional coarse aggregate partially by coconut shell to produce light weight concrete [1]. It was found that the strength of coconut shell aggregate concrete is comparatively less than conventional concrete but provides provision for lightweight structures. The addition of steel fibers to coconut shell concrete gave an increase in crack resistance, ductility and impact resistance [2].

Researchers compared the mechanical and bond properties with theoretical values recommended by Indian standards. It has been concluded that the bond strength of coconut shell concrete is higher than the specified standards for lightweight concrete given by BS 8110 and IS 456:2000 [3]. Oil palm shell and palm oil clinkers also have the potential to be manufactured into a structural light weight concrete. The density of this type of concrete is $20-25 \%$ lower than conventional concrete [4]. Coconut has granular grains at the bottom of the shell when observed under electron microscope. Hence, it was found that it can be used as a coarse aggregate in concrete [5]. Earlier studies have investigated on the strength characteristics of palm oil shell and coconut shell based light weight concrete. They concluded that coconut based concrete has enhanced characteristics than palm oil shell apart from being cost effective [6]. Researchers found that the durability characteristics like porosity, water absorption were found to be higher for coconut shell mixes than the control mix and the addition of admixtures into coconut shell aggregates have enhanced the properties of coconut shell concrete [7]. Past studies have found out that the replacement of cement with fly ash, micro silica fibres with $10 \%$ have resulted in greater strength than in normal coconut shell concrete [8]. It has been found that the addition of supplementary cementitious material (Alccofine) have provided higher strength only at a range of $5-15 \%$ [9].

\subsection{Research Significance}

From the earlier works it has been concluded that the coconut shell concrete has achieved less density having a limitation of reduction in compressive strength. In order to overcome this problem, Alccofine- a supplementary cementitious material having good mechanical properties could be partially replaced for cement. The reduction in strength due to coconut shell as aggregate in concrete could be overcome with the help of the cementitious supplementary material. 


\section{MATERIALS AND METHODS}

\subsection{Materials}

\subsubsection{Cement}

Ordinary Portland cement (Dalmia) cement of grade 53 procured from locally available dealers throughout the investigation. The cement being a binder material helps to bind the fine and coarse aggregate together and also filling the larger voids between aggregates. Cement had a specific gravity of 3.1 with consistency $32 \%$ and setting time 33 minutes. The properties of cement are shown in table 1.

\subsubsection{Alccofine 1203}

ALCCOFINE 1203 is a special admixture having glass content with high reactivity when undergone granulation, and it was procured from the local supplier. The properties of Alccofine are shown in table 2.

\subsubsection{Fine Aggregate}

River sand has been used throughout the investigation as the fine aggregate conforming to grading zone II as per IS 383:1970 [16]. The fineness modulus and specific gravity are 3.35 and 2.7 respectively.

Table 1 Properties of cement

Table 2 Properties of Alccofine

\begin{tabular}{|c|c|c|c|c|c|}
\hline S.No. & Properties & Observed value & S.No. & Test & Result \\
\hline 1. & Setting time & 30 minutes & 1. & Particle size distribution ( $\mu \mathrm{m})$ & 1.4 \\
\hline 2 & Specific gravity & 3.15 & 2. & d50 & 4.3 \\
\hline 3. & Consistency & $30 \%$ & 3. & d90 & 8.9 \\
\hline \multirow{2}{*}{\multicolumn{3}{|c|}{ Chemical composition }} & 4. & Bulk Density $\left(\mathrm{Kg}_{\mathrm{g}} \mathrm{m}^{3}\right)$ & 675 \\
\hline & & & 5. & Specific gravity & 2.87 \\
\hline \multicolumn{2}{|r|}{ Oxide } & Percent content & \multirow[t]{2}{*}{6.} & \multirow{2}{*}{$\begin{array}{l}\text { Marsh cone flow (with water to } \\
\text { ALCCOFINE } 1203 \text { ratio as 1.5) }\end{array}$} & \multirow[t]{2}{*}{29} \\
\hline & $\mathrm{CaO}$ & $60-67$ & & & \\
\hline & $\mathrm{SiO}_{2}$ & $17-25$ & \multicolumn{3}{|c|}{ Chemical composition } \\
\hline & $\mathrm{Al}_{2} \mathrm{O}_{3}$ & $3.0-8.0$ & 7. & $\mathrm{SiO}_{2}$ & $35.8 \%$ \\
\hline & $\mathrm{Fe}_{2} \mathrm{O} 3$ & $0.5-6.0$ & 8. & $\mathrm{Al}_{2} \mathrm{O}_{3}$ & $21.6 \%$ \\
\hline \multirow{2}{*}{\multicolumn{2}{|c|}{ Mgo }} & \multirow{2}{*}{$0.1-4.0$} & 9. & $\mathrm{Fe}_{2} \mathrm{O}_{3}$ & $1.3 \%$ \\
\hline & & & 10. & $\mathrm{CaO}$ & $33.9 \%$ \\
\hline \multicolumn{2}{|c|}{ Alkalies ( $\left.\mathrm{K}_{2} \mathrm{O}, \mathrm{Na} 2 \mathrm{O}\right)$} & $0.4-1.3$ & 11. & $\mathrm{SO}_{3}$ & $0.12 \%$ \\
\hline & $\mathrm{sOs}$ & $1.3-3.0$ & 12. & $\mathrm{MgO}$ & $6.3 \%$ \\
\hline
\end{tabular}

\subsubsection{Coarse Aggregate}

Natural coarse aggregate from local quarries are collected with maximum size of $20 \mathrm{~mm}$.

Coconut shell collected from oil mills and hotels were seasoned properly. The seasoned coconut shell are manually crushed using hammer. The crushed aggregate are made to sieve and aggregates passing through $20 \mathrm{~mm}$ sieve and retained on $12.5 \mathrm{~mm}$ are picked and are used at Saturated Surface Dry (SSD) condition. The sieve analysis and particle distribution are as shown in figure 1. 
L J Sanjeev Kumar, P Bhuvaneshwari, Moka Eswar and K Aditya Subramanian
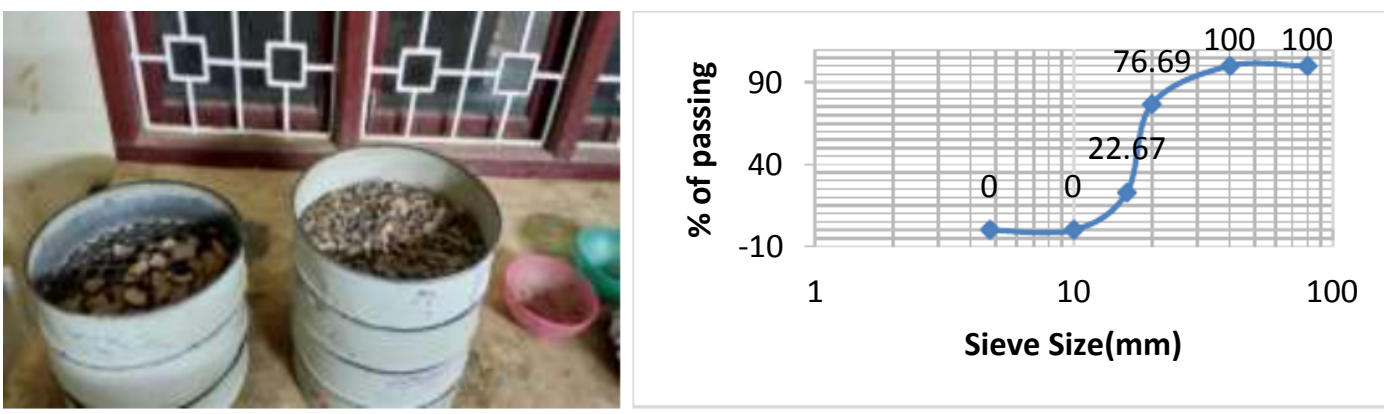

(a)

(b)

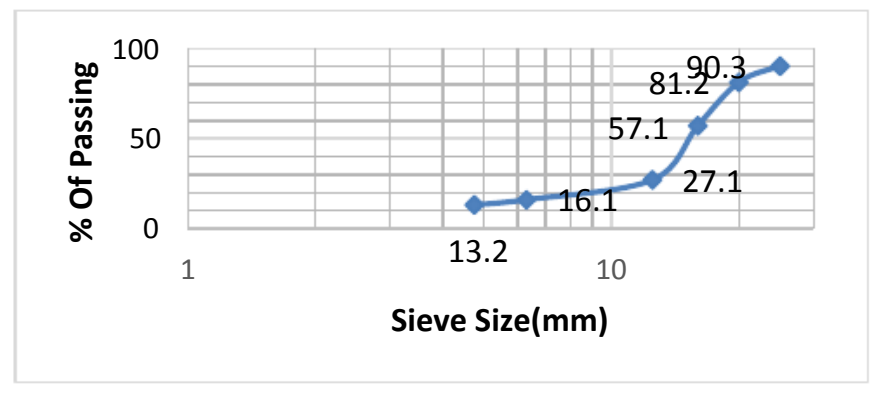

(c)

Figure 1 (a) Sieve Analysis of Coarse Aggregate; (b) Fineness modulus for conventional coarse aggregate; (c) Fineness modulus for coconut shell aggregate;

Table 3 Properties of coarse aggregate and coconut shell aggregate [15]

\begin{tabular}{|l|l|l|}
\hline Description & CA & CS \\
\hline Specific Gravity & 2.66 & 1.314 \\
\hline Water Absorption & $0.49 \%$ & $18.68 \%$ \\
\hline Surface Texture & Rough & $\begin{array}{l}\text { Smooth inner surface and } \\
\text { rough outer sturfice }\end{array}$ \\
\hline Shape & Angular & Flaky \\
\hline Impact Value & $20.13 \%$ & $6.94 \%$ \\
\hline Crushing Valne & $23.86 \%$ & $1.93 \%$ \\
\hline
\end{tabular}

\subsection{Casting and Testing of specimens}

\subsubsection{Mix proportion}

Mix design is carried out for achieving the required strength. The mix proportion arrived for M40 concrete is 1:1.212:2.179 along with water cement ratio 0.4 and slump 27mm [17]. Fresh concrete properties like workability were observed using slump. The obtained slump was true slump having no shear.

The mix ID provides the various mixes to be used in the whole project. The proportions for different mixes are as shown in table 4. 
Strength Characteristics of Alccofine Based Light Weight Concrete

Table 4 Proportions for Alccofine based lightweight concrete $\left(\mathrm{kg} / \mathrm{m}^{3}\right)$

\begin{tabular}{|c|c|c|c|c|c|c|}
\hline SL.NO & MIX ID & CEMENT & ALCCOFINE & FA & CA & $\begin{array}{c}\text { COCONUT } \\
\text { SHELL }\end{array}$ \\
\hline 1 & $\begin{array}{c}\text { Control Mix } \\
\text { MII }\end{array}$ & 492.9 & - & 597.5 & 1074.33 & - \\
\hline 2 & $\begin{array}{c}30 \mathrm{CS} \\
\mathrm{M} 2\end{array}$ & 492.9 & - & 597.5 & 752.03 & 157.5 \\
\hline 3 & $\begin{array}{c}30 \mathrm{CS} 6 \mathrm{~A} \\
\mathrm{MI}\end{array}$ & 492.9 & 29.574 & 597.5 & 752.03 & 157.5 \\
\hline 4 & $\begin{array}{c}30 \mathrm{CS} 8 \mathrm{~A} \\
\mathrm{M} 4\end{array}$ & 492.9 & 39.432 & 597.5 & 752.03 & 157.5 \\
\hline 5 & $\begin{array}{c}30 \mathrm{CS} \mathrm{10A} \\
\mathrm{MI5}\end{array}$ & 492.9 & 49.290 & 597.5 & 752.03 & 157.5 \\
\hline 6 & $\begin{array}{c}30 \mathrm{CS} 12 \mathrm{~A} \\
\mathrm{MI6}\end{array}$ & 492.9 & 59.148 & 597.5 & 752.03 & 157.5 \\
\hline
\end{tabular}

\subsubsection{Casting of specimens}

The present work involved in casting of 36 cubical specimens of size $(100 \mathrm{~mm} \times 100 \mathrm{~mm} \times 100$ $\mathrm{mm}$ ) in total for both conventional and coconut shell concrete. The average compressive strength of 3 specimens were calculated for both 7 and 28 days strength for all the mixes. Workability test and the cast specimens are shown in figure 3.

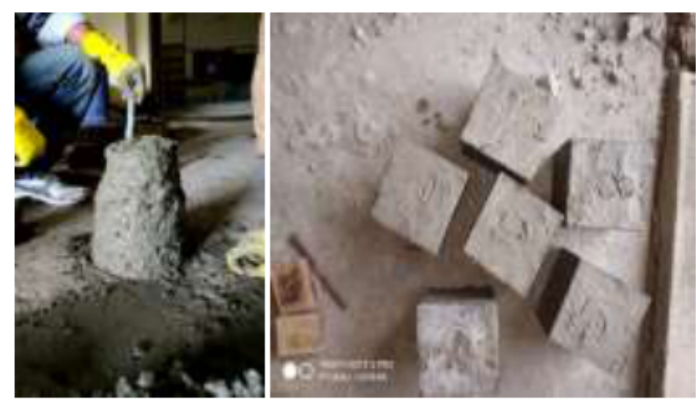

Figure 2 Fresh concrete slump and cubical specimens after 28day curing

\subsubsection{Testing of specimens}

After curing, the specimens were surface dried and tested under compressive load in CTM $3000 \mathrm{kN}$ capacity [18]. The failure of specimen is as shown in figure.

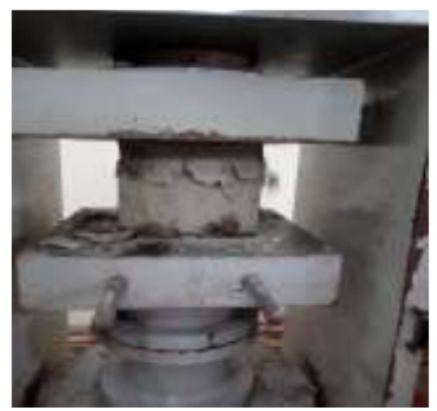

Figure 3 Compressive testing in CTM

\section{RESULTS AND DISCUSSIONS}




\subsection{Wet and Dry density}

After demoulding the weight of the specimens are measured and the dry density is calculated with respect to the volume of the specimen. After curing, the procedure is repeated to calculate the wet densities of specimens. The wet and dry densities of specimens are tabulated in table 5.

Table 5 Dry and wet densities of specimens

\begin{tabular}{|c|c|c|c|c|}
\hline Mix ID & $\begin{array}{c}\text { Dry Density } \\
\left(\mathbf{K g} \mathbf{~ m}^{\mathbf{3}}\right)\end{array}$ & $\begin{array}{c}\text { \% decrease in } \\
\text { dry density }\end{array}$ & $\begin{array}{c}\text { Wet Density } \\
\left(\mathbf{K g} \mathbf{~ m}^{\mathbf{3}}\right)\end{array}$ & $\begin{array}{c}\text { \% decrease in } \\
\text { wet density }\end{array}$ \\
\hline Control Mix (M1) & 2560 & - & 2591 & - \\
\hline 30CS (M2) & 2168 & 15.3 & 2279 & 12.04 \\
\hline 30CS 6A (M13) & 2180 & 14.84 & 2256 & 12.9 \\
\hline 30CS 8A (M4) & 2120 & 17.18 & 2194 & 18.09 \\
\hline 30CS 10A (M5) & 2110 & 17.57 & 2200 & 15.09 \\
\hline 30CS 12A (M6) & 2210 & 13.67 & 2279 & 12.04 \\
\hline
\end{tabular}

The wet and dry weights of the cubical specimens for all the mixes are noted. The conventional concrete having no addition of coconut shell has not given much variation in the density after curing. The density for mixes having $30 \%$ coconut shell has shown an increase of $3.5 \%$ after curing. This might be due to the absorbent nature of coconut shell resulting in increase of density.

\subsection{Compressive strength}

After demoulding, the specimens are surface dried. The ultimate load at which the failure has occurred is noted down and the compressive strength for different specimens are tabulated in table 6.

Table 6 Comparison of Compressive strength of specimens [18]

\begin{tabular}{|c|c|c|c|c|}
\hline Type of Mix & $\begin{array}{c}7 \text { Day strength } \\
\left(\mathrm{N} / \mathrm{mm}^{2}\right)\end{array}$ & $\begin{array}{l}\% \text { decrease } \\
\text { in strength }\end{array}$ & $\begin{array}{c}28 \text { Day strength } \\
\left(\mathrm{N} / \mathrm{mm}^{2}\right)\end{array}$ & $\begin{array}{l}\% \text { decrease in } \\
\text { strength }\end{array}$ \\
\hline Control Mix (M1) & 17.8 & - & 44.8 & - \\
\hline $30 \mathrm{CS}$ (M12) & 11.05 & 37.92 & 35.49 & 20.78 \\
\hline $30 \mathrm{CS} 6 \mathrm{~A}(\mathrm{M} 3)$ & 13.98 & 21.4 & 37.94 & 15.31 \\
\hline $30 \mathrm{CS} 8 \mathrm{~A}(\mathrm{M}-4)$ & 14.4 & 19.1 & 42.41 & 5.33 \\
\hline $30 \mathrm{CS} 10 \mathrm{~A}(\mathrm{MS})$ & 13.02 & 26.85 & 39.12 & 12.6 \\
\hline $30 \mathrm{CS} 12 \mathrm{~A}(\mathrm{M} 6)$ & 12.17 & 31.62 & 38.18 & 14.77 \\
\hline
\end{tabular}

It has been observed that the compressive strength has been reduced from $17.8 \mathrm{~N} / \mathrm{mm}^{2}$ (M1) to $11.05 \mathrm{~N} / \mathrm{mm}^{2}$ (M2) with replacement of $30 \%$ of coconut shell as coarse aggregate whereas for (M4) the partial replacement of cement with mineral admixture has enhanced the strength properties by $20 \%$ compared to (M2).

Compared to other mixes, (M4) with $8 \%$ of Alccofine replacement has given an effective restoration of strength.

\section{CONCLUSION}


Light weight concrete specimens were cast using coconut shell as partial replacement for conventional aggregate. Both dry and wet densities were checked. The specimens were tested for compressive strength. In order to overcome the reduction in strength of light weight concrete, cement is being partially replaced with Alccofine mineral admixture. The results are compared and following conclusions are arrived.

- Both dry and wet density got reduced in CS based concrete. All the combinations showed an average reduction of about $14.85 \%$, compared to that of control mix concrete.

- The compressive strength after 7 days of moisture curing was comparatively lesser than that of control concrete. Compared to Control Mix (M1), the reduction for CS30 (M2), CS30 A6 (M3), CS30 A8 (M4), CS30 A10 (M5), CS30 A12 (M6) are $37.9 \%, 21.46 \%, 19.1 \%, 26.9 \%, 31.6 \%$ respectively. Among the different combinations, CS30A8 shows less reduction.

- Similar performance were noticed in the specimens which were moist cured for 28 days. Compared to Control Mix (M1), the reduction compressive strength for CS30 (M2), CS30 A6 (M3), CS30 A8 (M4), CS30 A10 (M5), CS30 A12 (M6) are 20.8\%, $15.3 \%, 5.3 \%, 12.7 \%, 14.1 \%$. From the results the optimum mix is found to be CS30 A8 (M4).

- Without replacing cement with Alccofine, for CS30 (M2), the reduction in strength was $20.8 \%$ compared to control mix. Whereas the percentage reduction is brought to a lesser value of $5.3 \%$ for CS30 A8 (M4).

- There was a gradual increase in strength up to 7 days, from where the strength has increased exponentially till 28 days.

\section{REFERENCES}

[1] Apeksha Kanojia, Sarvesh K Jain, "Performance of coconut shell as coarse aggregate in concrete", Construction and Building Materials 140 (2017) 150-156.

[2] R. Robert Singh, R. Veera Kumar, T Nelson Ponnu Durai, I Iswarya, " Experimental investigation of coconut shell as partial replacement of coarse aggregate and adding steel fibres in concrete", International Journal of Civil Engineering and Technology (2017) Volume 8, Issue 8, pp 807-819.

[3] Gunasekaran K, Kumar PS, Lakshmipathy M, "Mechanical and bond properties of coconut shell concrete", Construction and Building Materials 25 (2011) 92-98.

[4] Md. Nazmul Huda, Mohd. Zamin Jumaat, "Palm oil industry's bi-products as coarse aggregate in structural lightweight concrete", Computers and Concrete, Vol. 19, No. 5 (2017) 515-526.

[5] Njeugna E, Ndapeu D, Bistac S, Drean J Y, Ngenefeme Foba J and Fogue M,"Contribution to the Characterization of the Coconut Shells (Coco Nucifera) of Cameroon" International Journal of Mechanics Structural ISSN 0974-312X Volume 4, Number 1 (2013), pp.1-23.

[6] Olanipekun E A, Olusola $\mathrm{K} \mathrm{O}$, Ata O, "A comparative study of concrete properties using coconut shell and palm kernel shell as coarse aggregates", Building and Environment 41 (2006) 297-301.

[7] Yashida Nadir, "Durability Properties of Coconut Shell Aggregate Concrete", KSCE Journal of Civil Engineering, DOI 10.1007/s12205-017-0063-6, 2017, 1-7.

[8] S. Prakash Chander, S Manivel, K Gunasekaran, A Jothiswaran, " An experimental investigation of partial replacement of cement using micro silica and fly ash in production 
L J Sanjeev Kumar, P Bhuvaneshwari, Moka Eswar and K Aditya Subramanian

of coconut shell concrete", International Journal of Civil Engineering and Technology (2017) Volume 8, Issue 4, pp. 1851-1859.

[9] Saurabh Gupta, Dr. Sanjay Sharma, Er. Devinder Sharma, "A Review on Alccofine : A supplementary cementitious material", International Journal of Modern Trends in Engineering and Research, Volume 02, Issue 08, August, 2018.

[10] Saurav, Ashok Kumar Gupta, "Experimental study of strength relationship of concrete cube and concrete cylinder using ultrafine slag Alccofine", International Journal of Scientific \& Engineering Research, Volume 5, Issue 5, May, 2014.

[11] Shannag M J, "Characteristics of lightweight concrete containing mineral admixtures", Construction and Building Materials 25 (2011) 658-662.

[12] Bureau of Indian Standards, IS 10262-2009, Concrete Mix Proportioning - Guidelines (First Revision), New Delhi.

[13] Bureau of Indian Standards, IS 1199-1959, Methods of Sampling and Analysis of Concrete, New Delhi, 2009.

[14] Bureau of Indian Standards, IS 12269-2013, Ordinary Portland Cement - Specification, New Delhi.

[15] Bureau of Indian Standards, IS 2386-1963, Methods of Test for Aggregates for Concrete, New Delhi.

[16] Bureau of Indian Standards, IS 383-1970, Coarse and Fine Aggregates from Natural Sources for Concrete, New Delhi.

[17] Bureau of Indian Standards, IS 456-2000, Plain and Reinforced Concrete-Code of Practice (Forth revision), New Delhi.

[18] Bureau of Indian Standards, IS 516-1959, Methods of Tests for Strength of Concrete, New Delhi. 